\title{
Successful Therapy of Pure Red Cell Aplasia Secondary to Plasma Cell Dyscrasia with Bolus Methylprednisolone
}

\author{
Yoshiko Matsuhashi, Taizo TASAKa, Eisuke Uehara, Tadashi KAmeI, Takahiro TAMURA and Masami NaGaI*
}

\begin{abstract}
A 65-year-old man, who is a Jehovah's Witness, was admitted to our hospital due to progressive anemia following a four-year history of biclonal gammopathy of no clinical significance. He was diagnosed with pure red cell aplasia (PRCA) associated with plasma cell dyscrasia. Despite a markedly decreased red blood cell count (hematocrit 5.6\%), the patient refused transfusion. He was intravenously administered bolus methylprednisolone. Reticulocytosis and recovery from anemia were observed on day 7 after the start of therapy. Secondary PRCA following plasma cell dyscrasia is a rare disorder; the treatments for this rare condition are discussed.
\end{abstract}

(Internal Medicine 40: 802-804, 2001)

Key words: biclonal gammopathy, Jehovah's Witness

\section{Introduction}

Pure red cell aplasia (PRCA) is a rare disorder characterized by normocytic anemia, reticulocytopenia and severe erythroid hypoplasia of the bone marrow with normal myeloid and megakaryocytic cell lineages (1). PRCA has been attributed to a variety of factors, including drugs, malnutrition, viral infections, autoimmune disorders, thymomas, chronic lymphocytic leukemia, malignant lymphoma and plasma cell dyscrasia (24). PRCA secondary to plasma cell dyscrasia is a rare condition, and optimal therapy for PRCA secondary to plasma cell dyscrasia has not been explored (2). We present a patient with PRCA secondary to plasma cell dyscrasia who is a Jehovah's Witness and on the basis of religious beliefs refused transfusion despite his severe anemia. The patient was successfully treated with bolus methylprednisolone (mPSL) therapy.

\section{Case Report}

In August 1998, a 65-year-old man with a ten-year history of diffuse panbronchiolitis (DPB) and a four-year history of $\operatorname{IgG} \lambda$ type and IgA $\kappa$ type biclonal gammopathy of no clinical significance, began to complain of progressive pallor, Catigability and dyspnea. Blood analyses revealed anemia with decreased red blood cells (RBC count, $153 \times 10^{4} / \mu \mathrm{l}$ ), hemoglobin $(\mathrm{Hb}, 5.4 \mathrm{~g} / \mathrm{dl})$ and hematocrit (Ht, 15.6\%). In September 1998, the patient was admitted to our hospital complaining of anemia and dyspnea. On admission, laboratory findings revealed anemia with markedly decreased RBC count (less than $100 \times 10^{4} /$ $\mu \mathrm{l}), \mathrm{Hb}(2.5 \mathrm{~g} / \mathrm{dl})$ and $\mathrm{Ht}(5.6 \%)$, depressed reticulocyte count $(0.5 \%)$, elevated $\operatorname{IgA}(1,781 \mathrm{mg} / \mathrm{dl})$, normal $\operatorname{IgG}(1,091 \mathrm{mg} / \mathrm{dl})$ and decreased $\operatorname{IgM}(28 \mathrm{mg} / \mathrm{dl})$. Bone marrow aspiration revealed a normocellular marrow with a markedly suppressed erythrocyte series (ME ratio $129: 1$ ) and normal plasma cell counts (3.8\%). Immunoelectrophoresis showed IgG $\lambda$ type and IgA $\kappa$ type proteins in serum (Fig. 1). Bone $\mathrm{Xp}$ of the whole body failed to reveal any pathological bone fracture or punchedout lesion. Serological tests and polymerase chain reaction (PCR) failed to detect parvovirus B19 infection. To test for a possible relationship between PRCA and agents previously administered for DPB, drug lymphocyte stimulation tests (DLST) were performed but the results were negative. The diagnosis of pure red cell aplasia was thus established. Because of his religious belief, the patient refused transfusion of red blood cells. Bolus methylprednisolone therapy (mPSL 1,000 $\mathrm{mg} /$ day/ 3 days) was thus administered by intravenous infusion. On the seventh day after the start of treatment with mPSL marked reticulocytosis (32.5\%) was detected (Fig. 2). The regimen was changed to $30 \mathrm{mg}$ oral PSL, daily and blood parameters continued to improve. Three liters of oxygen was administered from admission until his clinical symptoms improved. The patient was discharged from hospital at the end of November 1998 with fully improved blood parameters (RBC $409 \times 10^{4} /$ $\mu \mathrm{l}, \mathrm{Hb} 13.2 \mathrm{~g} / \mathrm{dl}$ and $\mathrm{Ht}$ 40.0\%). In September 1999, during tapering of the oral dose of PSL from $7.5 \mathrm{mg}$ to $5 \mathrm{mg}$, laboratory examination again revealed progressive anemia $(\mathrm{Hb} 9.2 \mathrm{~g} /$

From the Department of Medicine, Kagawa Prefectural Central Hospital, Takamatsu and *the First Department of Internal Medicine, Kagawa Medical University, Miki-cho

Received for publication October 26, 2000; Accepted for publication March 3, 2001

Reprint requests should be addressed to Dr. Taizo Tasaka, the Department of Medicine, Kagawa Prefectural Central Hospital, 5-4-16 Ban-cho, Takamatsu, Kagawa 760-8557 
$\mathrm{dl}, \mathrm{Ht} 22.0 \%)$, reticulocytopenia, elevated $\operatorname{IgA}(752 \mathrm{mg} / \mathrm{dl})$, and decreased $\mathrm{IgG}(553 \mathrm{mg} / \mathrm{dl})$ and $\mathrm{IgM}(22 \mathrm{mg} / \mathrm{dl})$. Bone marrow aspiration revealed a normocellular marrow with a markedly suppressed erythrocyte series (ME ratio $86: 1$ ). Following bo-

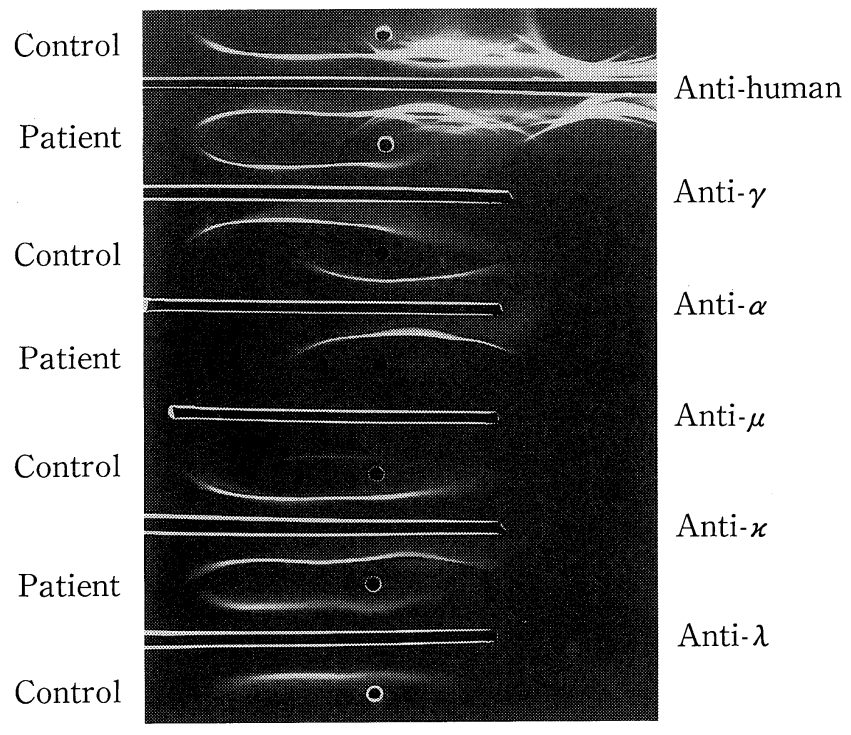

Figure 1. Immunoelectrophoresis of the patient. lus mPSL therapy, rapid recovery of anemia was again observed within two weeks.

\section{Discussion}

The current proposals to treat PRCA are conflicting, probably because PRCA is a rare disorder and occurs secondary to a wide variety of disorders (2-4). Plasma cell dyscrasia is a rare cause of secondary PRCA, accounting for less than $5 \%$ of the cases of secondary PRCA (2).

The etiology of PRCA cases secondary to plasma cell dyscrasia is unclear. Suppression of erythropoiesis by a cell- and/ or antibody-mediated immune mechanism is the most likely cause of idiopathic PRCA. Some studies demonstrated that autologous cytotoxic $\mathrm{T}$ cells inhibited colony formation by erythroid progenitor cells obtained from patients with PRCA (5). A recent report revealed clonal expansion of cytotoxic $\mathrm{T}$ cells in the peripheral blood of patients with myeloma (6). It is, thus, possible that such cytotoxic $\mathrm{T}$ cells inhibited erythropoiesis in our patient.

Idiopathic monoclonal gammopathy has been reported to be caused by reactivation of the B cell lineage as a result of continuous stimulation such as chronic inflammation (7). Our patient had a long history of DPB which might be related to the cause of biclonal gammopathy. Monoclonal gammaglobulin may be functional in some cases. Umlas et al demonstrated that serum from a PRCA patient with IgM $\kappa$ type monoclonal

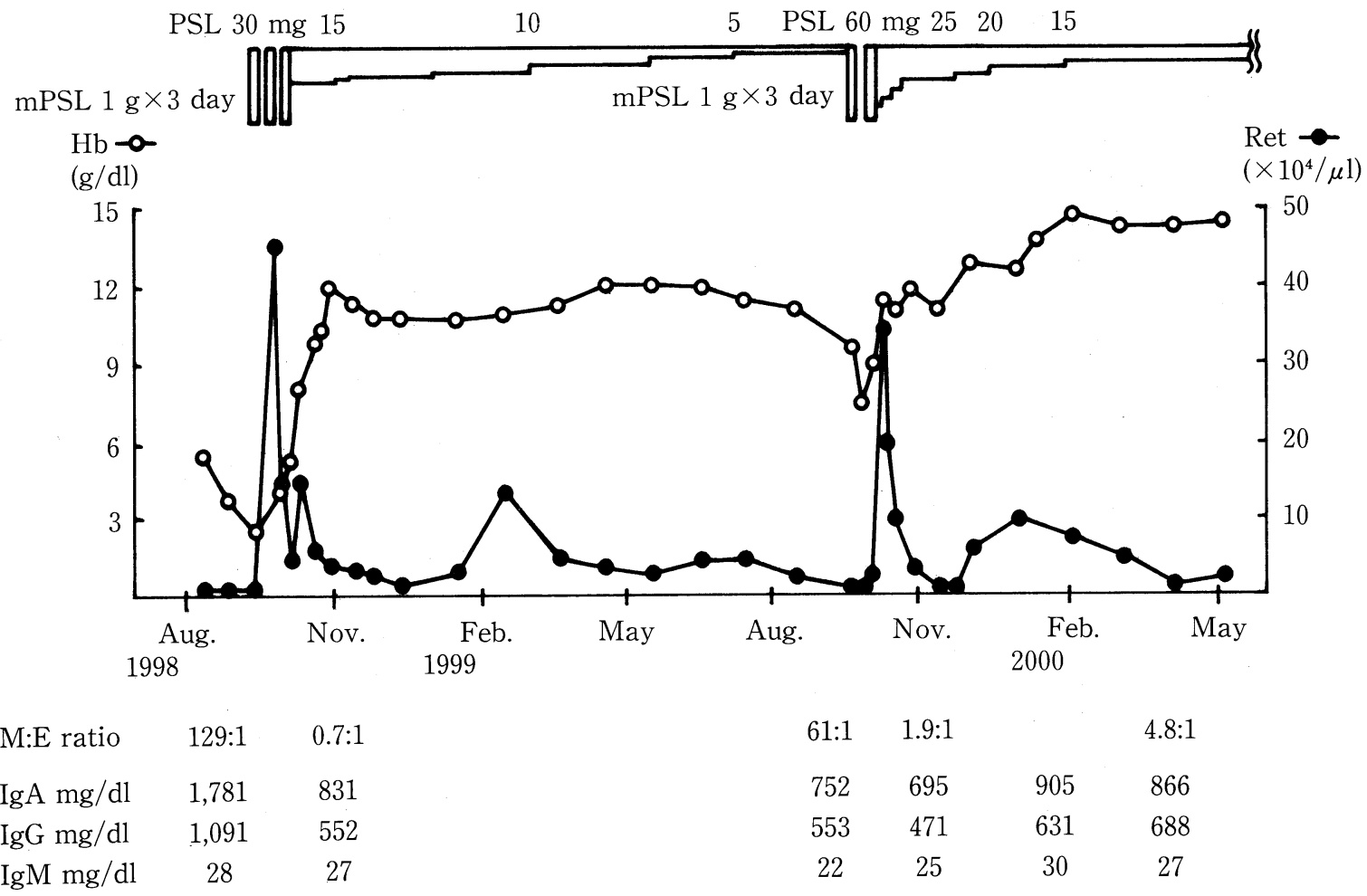

Figure 2. Clinical course of the patient. PSL: prednisolone, mPSL: methylprednisolone, Hb: hemoglobin, Ret: reticulocyte. 


\section{Matsuhashi et al}

gammopathy suppressed erythroid colony formation in a dosedependent manner (8). In our patient, the decrease in serum levels of IgA observed after bolus mPSL therapy was associated with the recovery of erythropoiesis. Thus, IgA $\kappa$ monoclonal protein may have suppressed the erythropoiesis in our patient.

The optimal therapy for PRCA secondary to plasma cell dyscrasia is unknown. Cyclosporin A (CyA), bolus mPSL therapy, oral PSL, cyclophosphamide (CPM), and a combination of PSL and CPM were reportedly effective in $73 \%, 60 \%$, $50 \%, 43 \%$ and $87 \%$ of patients with secondary PRCA, respectively (2). CyA, a T cell-specific inhibitor, induced rapid reticulocytosis within two weeks in half of the patients, but in the other patients the hematological response was observed after more than 3 months (2). Bolus mPSL therapy has been used in the treatment of aplastic anemia, with rapid recovery of hematopoiesis in cases in which it was effective (9). Although the precise mechanism of action of MPSL is still unclear, we believe it probably reduces the suppressive effect of $T$ cells on hematopoietic stem cells $(10,11)$. Bolus $\mathrm{mPSL}$ has been reported to be an effective, non-myeloabortive therapy for refractory myeloma, which leads to a rapid decrease in M-protein (12). Bolus mPSL therapy would thus be effective either if erythropoiesis is inhibited by cytotoxic $\mathrm{T}$ cells or through an antibody-mediated immune mechanism. Since the response of our patient to bolus mPSL therapy was rapid and reproducible, this therapy may become the treatment choice for patients with PRCA, especially for those with PRCA secondary to plasma cell dyscrasia.

\section{Reference}

1) Ammus SS, Yunis AA. Acquired pure red cell aplasia. Am J Hematol 24: 311-326, 1987.

2) Mamiya $S$, Itoh $T$, Miura $A B$. Acquired pure red cell aplasia in Japan. Eur J Haematol 59: 199-205, 1997.

3) Dessypris EN. The biology of pure red cell aplasia. Semin Hematol 28: 275-284, 1991.

4) Freedman MH. Pure red cell aplasia in childhood and adolescence: pathogenesis and approaches to diagnosis. Br J Haematol 85: 246-253, 1993.

5) Masauzi N, Tanaka J, Watanabe M, et al. Primary Waldenstrom's macroglobulinemia associated with pure red cell aplasia in which Ts/c lymphocytes inhibiting erythroid precursors were detected. Rinsho Ketsueki 34: 355-361, 1993.

6) Raitakari M, Brown RD, Sze D, et al. T-cell expansions in patients with multiple myeloma have a phenotype of cytotoxic $\mathrm{T}$ cells. Br J Haematol 110: 203-209, 2000.

7) Kyle RA. Monoclonal gammopathy and multiple myeloma in the elderly. Baillieres Clinical Haematol 1: 533-557, 1987.

8) Umlas J, Kaufman M, MacQueston C, Sorba S, Dainiak N. A cryoglobulin with cold agglutinin and erythroid stem cell suppressant properties. Transfusion 31: 361-364, 1991.

9) Bacigalupo A, Giordano D, Van Lint MT, Vimercati R, Marmont AM. Bolus methylprednisolone in severe aplastic anemia. N Engl J Med 300: 501-502, 1979 (letter).

10) Gluckman E, Devergie A, Poros A, Degoulet P. Results of immunosupression of 170 cases of severe aplastic anemia. Br J Haematol 51: 541-550, 1982.

11) Bagby GC Jr, Goodnight SH, Mooney WM, Richert-Boe K. Prednisoneresponsive aplastic anemia: A mechanism of glucocorticoid action. Blood 54: 322-333, 1979.

12) Gertz MA, Garton JP, Greipp PR, Witzig TE, Kyle RA. A phase II study of high-dose methylprednisolone in refractory or relapsed multiple myeloma. Leukemia 9: 2115-2118, 1995. 